\title{
Induksi Kalus Tanaman Kentang Dombu (Solanum tuberosum L.) Secara In Vitro Dengan Penambahan Ekstrak Tomat Dan Air Kelapa
}

\section{Callus Induction of Potato (Solanum tuberosum L.) of c.v. Dombu In Vitro On Ms Medium With Additional Of Tomato Extract And Coconut Water}

\author{
Riska Sari*), Asri P. Paserang, Ramadanil Pitopang, I Nengah Suwastika \\ Jurusan Biologi, Fakultas MIPA, Universitas Tadulako, Palu
}

\begin{abstract}
The research of In vitro callus induction in Dombu potato (Solanum tuberosum L) using the concentrations of tomato extracts and coconut water was carried out from May to September 2018 in the Tissue Culture Laboratory, Biology Department, Faculty of Mathematics and Natural Sciences, Tadulako University. The research was aimed to know the influences of the concentrations of tomato extracts and coconut water against on to the formation of the callus in on Dombu potato (S. tuberosum $\mathrm{L}$ ) by In vitro. This research was conducted with based on Completely Randomized Design (CRD) methods Rancangan Acak Lengkap (RAL) with seven treatments by which each treatment had four repetitions replication.and each culture bottle used and two explants on each botle. The treatment were: $\mathrm{T} 1\left(\mathrm{MS}_{0}+10 \%\right.$ tomato extracts), $\mathrm{T} 2\left(\mathrm{MS}_{0}+15 \%\right.$ tomato extracts), $\mathrm{T} 3\left(\mathrm{MS}_{0}+20 \%\right.$ tomato extracts), $\mathrm{T} 4\left(\mathrm{MS}_{0}+20 \%\right.$ coconut water), $\mathrm{T} 5\left(\mathrm{MS}_{0}+25 \%\right.$ coconut water), $\mathrm{T} 6\left(\mathrm{MS}_{0}+30 \%\right.$ coconut water), $\mathrm{T} 7$ (control/MS0). The results showed that the fastest callus formed in was on the treatment T6, was the fastest of allwith in average of 1.5 HST days after inoculation . The best media used for the growth of the callus was found on T7 (control).
\end{abstract}

Keywords: Potato, Callus, Tomato Extracts, Coconut Water

\begin{abstract}
ABSTRAK
Penelitian Induksi Kalus Tanaman Kentang Dombu (Solanum tuberosum L.) secara In vitro dengan penambahan Konsentrasi Ekstrak Tomat dan Air Kelapa, telah diilaksanakan pada bulan Mei sampai September 2018 di Laboratorium Kultur Jaringan Jurusan Biologi Fakultas Matematika dan Ilmu Pengetahuan Alam Universitas Tadulako. Penelitian ini bertujuan untuk mengetahui pengaruh konsentrasi ekstrak tomat dan air kelapa terhadap pembentukan kalus tanaman kentang (S. tuberosum L.) secara in vitro. Penelitian ini dilakukan berdasarkan Rancangan Acak Lengkap (RAL) dengan 7 perlakuan dan diulang sebanyak 4 kali. dan Dalam setiap satu botol kultur menggunakan ditanam 2 eksplan. Perlakuan yang dicobakan terdiri dari: $\mathrm{T} 1\left(\mathrm{MS}_{0}+\right.$ ekstrak tomat $\left.10 \%\right), \mathrm{T} 2\left(\mathrm{MS}_{0}+\right.$ ekstrak tomat $15 \%)$, T3 $\left(\mathrm{MS}_{0}+\right.$ ekstrak tomat $\left.20 \%\right)$, T4 $\left(\mathrm{MS}_{0}+\right.$ air kelapa $\left.20 \%\right)$, T5 $\left(\mathrm{MS}_{0}+\right.$ air kelapa $25 \%)$, T6 ( $\mathrm{MS}_{0}+$ air kelapa30 \%), T7 (Kontrol/MS0). Hasil penelitian menunjukkan bahwa Hari pembentukan kalus tercepat, yang terbentuk lebih cepat pada perlakuan T6 dengan rata-rata 1,5 HST. Media yang paling baik digunakan pada pertumbuhan kalus terdapat adalah pada T7 (Kontrol).
\end{abstract}

Kata kunci: Kentang, Kalus, Ekstrak Tomat, Air Kelapa 


\section{LATAR BELAKANG}

Tanaman kentang

(Solanum

tuberosum L.) merupakan salah satu jenis sayuran yang terdapat di Indonesia yang memiliki kandungan karbohidrat dan gizi tinggi. Kentang juga dapat dijadikan alternatif pangan karbohidrat selain beras (Gunarto, 2003). Di Indonesia, konsumsi kentang sebagai bahan pangan berkembang cukup pesat, dimana dalam rumah tangga konsumsi kentang pada tahun 2002-2012 rata-rata meningkat sebesar $1,76 \%$ setiap tahunnya. Nilai gizi kentang relatif berimbang yaitu mengandung air 78\%, karbohidrat $18 \%$, protein $2 \%$, mineral dan vitamin C (Rubatzky dan Yamaguchi, 1998).

Sulawesi Tengah tepatnya di Desa Dombu Kec. Marawola Kab. Sigi, Sulawesi Tengah, terdapat tanaman kentang lokal yang tumbuh di dataran tinggi yang di beri nama kentang dombu. Dombu tersebut berasal dari nama desa. Ciri khas dari kentang ini adalah ukurannya yang kecil. Masyarakat lokal melakukan Pembudidayaan kentang dombu secara konvensional menggunakan umbi sebagai bibit. Kelemahan pembibitan menggunakan umbi yaitu jika umbi yang digunakan terserang penyakit /patogen maka generasi selanjutnya akan berpotensi terserang penyakit patogen dan waktu pertunasan umbi tidak serentak sehingga hasil panen akan berdampak pada harga kentang dombu di pasar tradisional Palu. Jika hal ini tidak ditangani maka kentang dombu tidak dapat bersaing dengan kentang daerah lainnya yang lebih unggul dan kentang dombu tersebut menjadi berkurang.

Menurut Duriat (1987), upaya yang dapat dilakukan untuk meningkatkan produktivitas kentang dapat dilakukan salah satunya dengan teknik mikropropagasi yaitu pemanfaatan teknik kultur jaringan tanaman untuk perbanyakan tanaman. Keunggulan perbanyakan tanaman kentang melalui kultur jaringan dibandingkan dengan metode lain adalah dapat menghasilkan bibit bebas patogen. Hal ini karena cendawan dan bakteri dapat berkembang dengan cepat dalam kondisi in vitro, sehingga hanya tanaman yang benarbenar bersih (bebas cendawan dan bakteri) yang dipelihara (Zulkarnain, dkk, 2005).

Zat pengatur tumbuh berupa auksin dan sitokinin dapat diperoleh secara alami dari bahan organik seperti ekstrak tomat dan air kelapa. Bahan-bahan alami yang digunakan dalam kultur jaringan ini jauh lebih ekonomis dibandingkan zpt sintetik. Selain harganya yang murah, bahan-bahan tersebut mudah didapat dan bahkan jarang dimanfaatkan.

Buah tomat matang megandung hormon sitokinin yang aktif (Dwiani,dkk. 2009, Bhojwani dan Razdan, 1983), 
berperan dalam pembelahan sel dan pembentukan tunas. Kadar sitokinin eksogen yang berasal dari kombinasi tersebut menyebabkan pembelahan sel pada jaringan meristem dapat terus ditingkatkan aktifitasnya.

Air kelapa mengandung ZPT alami yang termasuk dalam golongan sitokinin (Priyono dan Danimihardja, 1991). Air kelapa merupakan senyawa organik yang sering digunakan dalam aplikasi teknik kultur jaringan. Karena air kelapa mengandung 1,3 diphenilurea, zeatin, zeatin gluoksida, dan zeatin ribosida (Armini dkk, 1992), dan harganya yang murah.

Penelitian ini bertujuan untuk mengetahui pengaruh konsentrasi ekstrak tomat dan air kelapa terhadap pembentukan kalus tanaman kentang (Solanum tuberosum L.) secara in vitro.

\section{BAHAN DAN METODE}

Penelitian dilaksanakan pada bulan Mei sampai September 2018 di Laboratorium Kultur Jaringan Jurusan Biologi Fakultas Matematika dan Ilmu Pengetahuan Alam Universitas Tadulako. Penelitian ini menggunakan Rancangan Acak Lengkap (RAL) dengan 7 perlakuan setiap perlakaun diulang sebanyak 4 kali dan setiap satu botol kultur menggunakan 2 eksplan.
Alat-alat yang digunakan terlebih dahulu direndam khususnya botol kultur kemudian disterilisasi. Media yang digunakan dalam teknik kultur jaringan ini adalah media MS (Murashige \& Skoog). Hal pertama yang perlu dilakukan adalah menimbang bahan yang digunakan yaitu media MS instan, gula, agar dan penambahan ZPT alami yaitu ekstrak tomat dan air kelapa. Kemudian eksplan yang digunakan di sterilkan dengan menggunakan sunlight dan bayclin. Eksplan yang steril dan telah dipotong per nodus, ditanam dalam media perlakuan.

\section{HASIL DAN PEMBAHASAN}

Pertumbuhan kalus dihitung berdasar kan kecepatan eksplan menunjukan tandatanda membentuk kalus pada hari setelah tanam (HST).

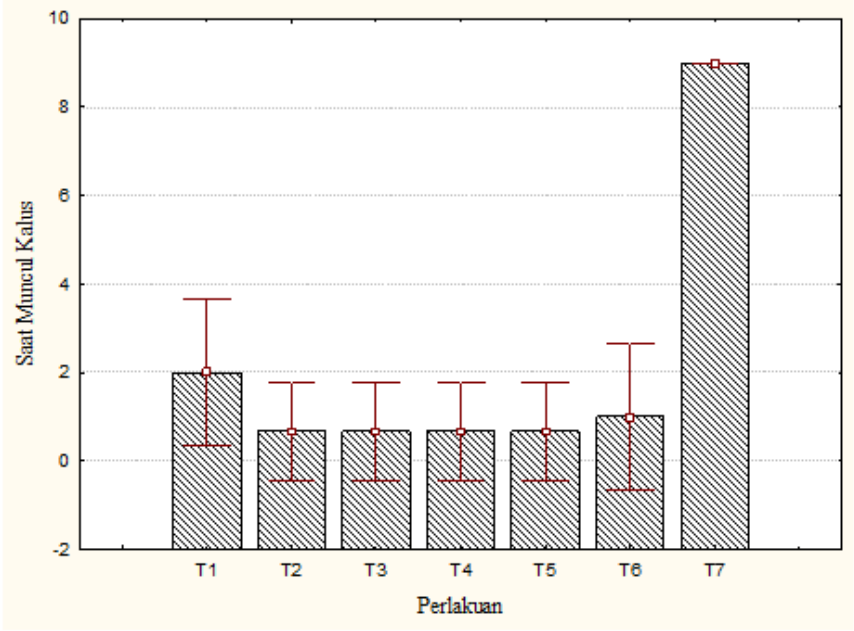

Gambar 1 Pengaruh Konsentrasi medium perlakuan terhadap munculnya kalus. Hasil sidik ragam diperoleh menunjukkan adanya berbedaan nyata. Nilai Saat munculnya kallus dinyatakan sebagai HST (Hari Setelah 
Tanam) adalah nilai rata-rata dan \pm SD.

Keterangan :

$\mathrm{T} 1=\mathrm{MS}_{0}+$ ekstrak tomat $10 \%$

$\mathrm{T} 2=\mathrm{MS}_{0}+$ ekstrak tomat $15 \%$

$\mathrm{T} 3=\mathrm{MS}_{0}+$ ekstrak tomat $20 \%$

$\mathrm{T} 4=\mathrm{MS}_{0}+$ air kelapa $20 \%$

$\mathrm{T} 5=\mathrm{MS}_{0}+$ air kelapa $25 \%$

$\mathrm{T} 6=\mathrm{MS}_{0}+$ air kelapa30 \%

$\mathrm{T} 7=\mathrm{MS}_{0}$

Tabel 1. Tipe kalus Solanum tuberosum pada berbagai perlakuan

\begin{tabular}{|c|c|c|c|}
\hline \multirow{2}{*}{ Periakuan } & \multicolumn{3}{|c|}{ Ulangen } \\
\cline { 2 - 4 } & 1 & 2 & 3 \\
\hline T1 & Remiah & - & Remah \\
\hline T2 & Remah & - & - \\
\hline T3 & - & - & Remah \\
\hline T4 & - & Remah & - \\
\hline T5 & Remah & - & Remah \\
\hline T6 & - & - & Remah \\
\hline T7 & Intermediet & Intermediet & Thy \\
\hline
\end{tabular}

Keterangan : 1) T1, T2, T3, T4, T5, T6 dan $\mathrm{T} 7$

2) (-) Tidak tumbuh kalus

Tabel 2. Warna kalus Solanum tuberosum pada berbagai perlakuan

\begin{tabular}{|c|c|c|c|}
\hline \multirow{2}{*}{ Perlakum } & \multicolumn{3}{|c|}{ Ulangan } \\
\hline & 1 & 2 & 3 \\
\hline TI & Putih kckuningan & - & Putilh kekuningan \\
\hline 12 & Putih kekuningan & * & * \\
\hline 13 & - & + & Putib kekuningan \\
\hline T4 & - & Coklat & - \\
\hline T5 & Putih kekuningan & * & $*$ \\
\hline T6 & $\cdot$ & * & Putih kekuningan \\
\hline 17 & Coklat & Putih kckuningan & Putih kekuningan \\
\hline
\end{tabular}

Keterangan : 1) T1, T2, T3, T4, T5, T6 dan $\mathrm{T} 7$

2) (-) Tidak tumbuh kalus

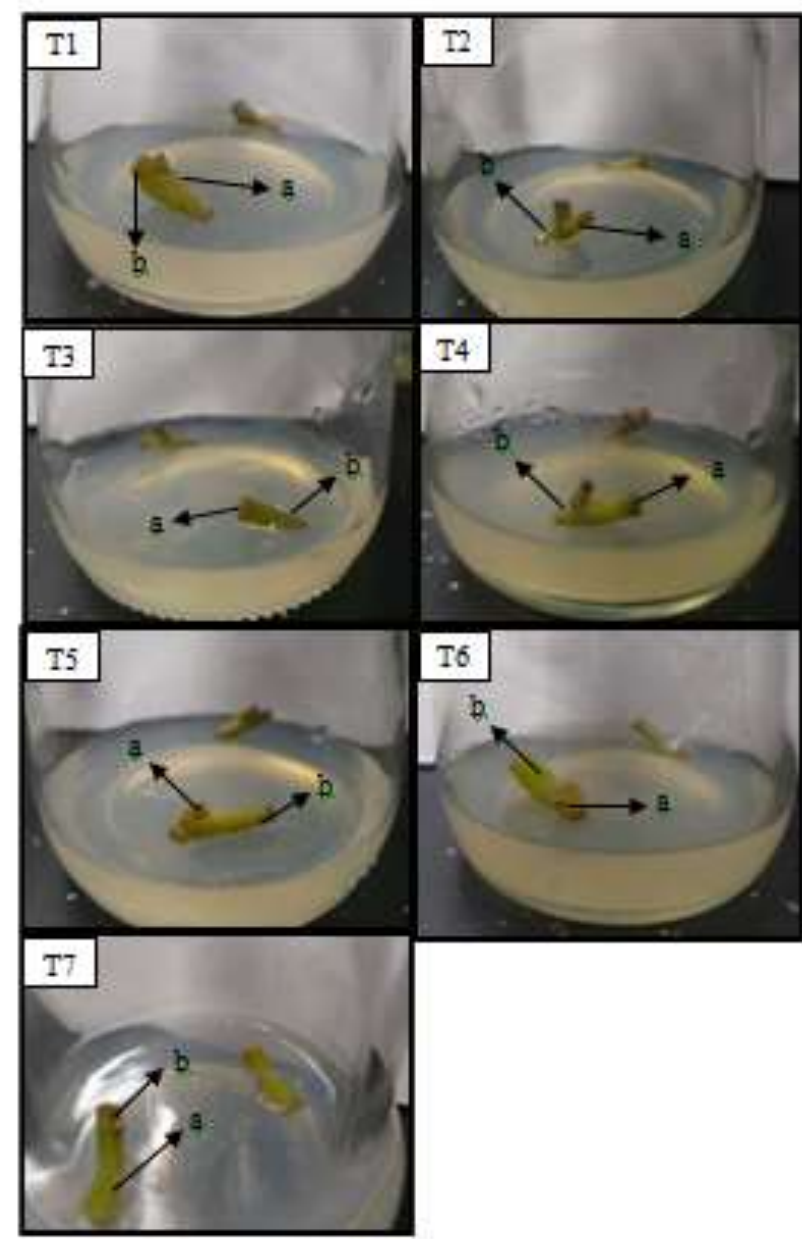

Gambar 2 Morfologi kalus pada media perlakuan, umur 20 HST setelah muncul kalus

Keterangan :

1) $\mathrm{T} 1$ = Kalus berwarna putih kekuningan dan remah

$\mathrm{T} 2$ = Kalus berwarna putih kekuningan dan remah

T3 = Kalus berwarna putih kekuningan dan remah

T4 = Kalus berwarna coklat dan remah

T5 = Kalus berwarna putih kekuningan dan remah

T6 = Kalus berwarna putih kekuningan dan remah

$\mathrm{T} 7=$ Kalus berwarna coklat, putih kekuningan dan bertipe remah dan intermediet 
2) a. Callus b. Eksplan

Pembentukan kalus yang terbentuk lebih cepat pada perlakuan T6 dengan ratarata 1,5 HST. Sedangkan pada perlakuan T2, T3, T4 dan T5 menunjukan adanya pertumbuhan kalus, namun pertumbuhan kalus pada perlakuan T2, T3, T4 dan T5 tidak secepat perlakuan T6. Jika dibandingkan dengan penelitian Parera (1997), tingkat konsentrasi air kelapa 20\% pada tanaman anggrek memperlihatkan respon yang sangat berbeda terhadap pertumbuhan sel kalus dibandingkan dengan konsentrasi 30\%. Karena makin tinggi konsentrasi air kelapa makin sedikit pertumbuhan sel kalus yang dihasilkan. Akan tetapi perlakuan subkultur konsentrasi air kelapa $20 \%$ dan 25\%, seharusnya memberikan respon terbaik pada pembentukan sel kalus. Namun hal ini tidak sesuai dengan hasil penelitian Aguzaen (2009), yang menyatakan bahwa konsentrasi $25 \%$ air kelapa secara nyata meningkatkan pertumbuhan sel kalus yang sangat baik.

Pada perlakuan T2 dan T3 menunjukan adanya pertumbuhan kalus tetapi tidak secepat perlakuan $\mathrm{T} 1$ yaitu $\mathrm{MS}_{0}$ + ekstrak tomat $10 \%$. Hal ini karena perlakuan T2 dan T3 merupakan kombinasi $\mathrm{MS}_{0}+$ ekstrak tomat $15 \%$ dan $\mathrm{MS}_{0}+$ ekstrak tomat $20 \%$, dimana ekstrak tomat pada T2 dan T3 banyak digunakan, sehingga pertumbuah kalus pada perlakuan
T2 dan T3 terhambat. Hal ini mungkin karena adanya asam Caumarinat yang terkandung pada buah tomat, yang merupakan salah satu zat penghambat yang dapat memperhambat pertumbuhan kalus. Sedangkan menurut Nursetiadi (2008), Hal ini dapat juga disebabkan karena pemberian auksin eksogen dari ekstrak tomat, masih berada dalam konsentrasi suboptimal sehingga respon eksplan untuk pertumbuhan kurang optimal. Selain itu dimungkinkan juga karena perbandingan antara auksin dengan sitokinin yang rendah, yakni sitokinin lebih rendah dari pada auksin, sehingga terjadi ketidak seimbangan pada eksplan dan menyebabkan pembentukan kalus jadi terhambat. Jumlah kalus diperoleh dari perlakuan ekstrak tomat konsentrasi $10 \%$ yaitu dengan rata-rata 2 HST menunjukkan respon positif eksplan terhadap pemberian zpt dalam konsentrasi yang efektif.

Konsentrasi auksin dalam ekstrak tomat memberikan pengaruh dalam pertumbuhan kalus karena auksin dapat membantu dalam pembesaran sel kalus. Auksin dalam ekstrak tomat yang diberikan dapat berinteraksi dengan sitokinin endogen untuk merangsang pembentukan sel kalus. (George and Sherrington) (1984) menyatakan bahwa auksin yang diberikan secara tunggal akan berinteraksi dengan zpt endogen untuk memacu pembelahan sel. Marliah dkk. (2010), menyatakan bahwa 
ekstrak tomat mengandung auksin IAA sehingga dapat meningkatkan potensi tumbuh, kecepatan tumbuh tanaman.

Berdasarkan pengamatan morfologi kalus, tipe kalus yang dihasilkan dalam setiap perlakuan, dapat dilihat pada Gambar 2 dan Tabel 1 Hasil pengamatan menunjukkan adanya tipe kalus yang berbeda-beda. Pada perlakuan T1 sampai T6 dapat menghasilkan tipe kalus remah, pada perlakuan kontrol (T7) tipe kalusnya baik karena bersifat remah dan intermediet. Kalus yang baik memiliki tekstur remah (friable) setiap perlakuan menghasilkan tekstur kalus yang sama yakni bertekstur remah. Seperti pada penelitian (Lizawati, 2012) tekstur kalus yang remah dianggap baik karena dapat meningkatkan aerasi oksigen antar sel dan mudah dipisahkan menjadi sel-sel tunggal pada kultur suspensi. Kalus yang memiliki tekstur kompak umumnya memiliki ukuran sel yang kecil dengan sitoplasma yang padat, mempunyai inti sel yang besar dan butir pati (kandungan karbohidrat) yang banyak. Sedangkan kalus tipe intermediet merupakan massa kalus yang terdiri dari kelompok sel-sel yang sebagian kompak dan sebagian lainnya remah.

Hasil pengamatan secara visual warna kalus pada, seperti disajikan pada tabel 2, menunjukkan bahwa rata-rata kalus yang terbentuk tiap perlakuan yang diuji menghasilkan warna yang berbeda-beda.
Perbedaan warna kalus yang terjadi pada tiap perlakuan menunjukkan bahwa tingkat perkembangan kalus berbeda-beda. Perubahan warna dari putih kekuningan menjadi kuning kecoklatan disebabkan oleh semakin dewasanya umur sel atau jaringan kalus dan menandakan terjadinya reaksi enzimatik yang mengarah pada sintesis senyawa fenol yang disebut browning (pencoklatan) (Santosa dan Nursandi, 2004). Menurut Abdullah dkk. (1987), selsel yang sehat akan menunjukkan warna kuning bening dan akan berubah menjadi kecolatan seiring dengan pertumbuhan kalus yang semakin tua. Warna kalus semakin gelap (kecoklatan) berarti pertumbuhan kalus semakin menurun.

Berdasarkan hasil penelitian dapat disimpulkan bahwa. Pada perlakuan T7 (kontrol) merupakan media yang paling baik dalam pertumbuhan kalus dibandingkan dengan penambahan ekstrak tomat dan air kelapa. Jika ingin menggunakan media dengan penambahan ekstrak tomat, konsentrasi yang digunakan disarankan lebih rendah karena kandungan asam Caumarinat yang terkandung pada buah tomat, yang merupakan salah satu zat penghambat yang dapat memperhambat pertumbuhan kalus. 


\section{DAFTAR PUSTAKA}

Abdullah, M.A., Ali,A.M., Marziali,M. dan Arif, A.B. (1987). Estabilisment of cell suspension cultures of Morinda elliptica for the production of anthraquinoes. Plant Cell Tissue and Organ Culture. 54: 173-182.

Aguzaen, H. (2009). Respon Pertumbuhan Bibit Stek Lada (Piper nisrum L.) Terhadap Pemberian Air Kelapa dan Berbagai Jenis CMA. Agronobis Jurnal, Vol. 1, No. 1. Hal 45.

Armini, N.M., Wattimena, G.A. dan Gunawan L. W. (1992). Perbanyakan Tanaman, Dalam G.A. Wattimena., N. A. Mattjik., E. Samsudin, N,M.A. Wiendi, dan A. Ernawati (Penyusun). Bioteknologi Tanaman. Laboratorium Kultur Jaringan Tanaman, Pusat Antar Universitas, Bogor:IPB. 307 hlm.

Bhojwani, S.S. and Radzan, M.K. (1983). Plant Tissue Culture: Theory and Practice. New York: Elvisier Science Publishing Company.

Duriat, A. S. (1987). Heat treatment as a mean of eliminating Potato Leaf Roll Virus from seed of potato. Prosiding Mid Elevation Potato Seminar. Lembang: 47-54.

Dwiani, RA. Purwantoro, A. Indrianto dan E. Semiarti. (2009). Peningkatan Kecepatan Pertumbuhan Embrio Anggrek Vanda tricolor Lindl. pada Medium Diperkaya dengan Ekstrak Tomat. Prosiding Seminar Biologi Nasional XX.UIN-Malang, 24-25 Juli 2009. 590-596

George, E. F., and Sherrington, P. D. (1984). Plant Propagation By Tissue Culture, Exegetics Limited, England.

Gunarto, A. (2003). Pengaruh Penggunaan Ukuran Bibit terhadap Pertumbuhan,
Produksi dan Mutu Umbi Kentang Bibit G4 (Solanum tuberosum L.) Jurnal Sains.5,173-179.

Lizawati. (2012). Induksi Kalus Embrionik Dari Eksplan Tunas Apikal Tanaman Jarak Pagar (Jatropha curcas L.) Dengan penggunaan 2,4 D dan Tdz. Jurnal Natural Science.Vol 1:No. 2 April-Juni 2012.

Marliah, A., Nasution, M., dan Azmi, S, (2010), Pengaruh Masa Kadaluarsa dan Penggunaan Berbagai Ekstrak Bahan Organik Terhadap Viabilitas dan Vigor Benih Semangka (Citrullus vulgaris Schard)', Agrista, vol. 14, no. 2 , hal. 44-50.

Nursetiadi, E. (2008) Kajian Media Tanam dan Konsentrasi BAP Terhadap Multiplikasi Tanaman Manggis (Gracinia mangostana) Secara in vitro, Fakultas Pertanian Universitas Sebelas Maret, Surakarta.

Parera, D,F. (1997). Pengaruh tingkat konsentrasi air kelapa terhadap pertumbuhan dan perbanyakan tanaman anggrek Dendrobium spp. melalui teknik kultur jaringan. GOTI. Jurnal Ilmu Pengetahuan dan Teknologi Universitas Pattimura. Vol. 2: 57-64.

Priyono dan Daminihardja.(1991). Peranan air kelapa terhadap produksi tunas adventif in vitro beberapa varietas kopi Arabika. Peta Perkebunan. Jember. hlm. 57-61.

Rubatzky, V.E., and Yamaguchi, M. (1998). Sayuran Dunia 1 : Prinsip, Produksi dan Gizi. Herison, C., penerjemah. Bandung (ID): Institut Teknologi Bandung. Terjemah dari: World Vegetable 1 : Principal, Production and Nutrition. 
Santoso, U., dan Nursandi, F., (2004). Kultur Jaringan Tanaman. Penerbit UMM. Malang.

Zulkarnain. B. Ichwan dan Rini A., 2005. Mikropropagasi Kentang (Solanum tuberosum L.) cv.Granola: Pengaruh Priode Gelap Pada Awal Kultur Dan Pengaruh Konsentrasi Kinetin Pada Kultur Lanjutan. Jurnal Agronomi. Vol. 9, No. 1. Hal 5-8.

Induksi Kalus Tanaman Kentang Dombu (Solanum tuberosum L.) Secara In Vitro Dengan Penambahan Ekstrak Tomat Dan Air Kelapa 